\title{
Detection and differentiation of carbapenemase production in carbapenem-resistant Enterobacteriaceae by the novel modified Carba NP test
}

\author{
Bore Kong1', Farida Noothong2, Panyupa Pankhong33, Pitak Santanirand4, Noppadon Jumroon ${ }^{3 *}$ \\ 1 Master of Science in Medical Technology Program, Faculty of Allied Health Sciences, Naresuan University, Phitsanulok, Thailand \\ 2 Master of Science in Biomedical Sciences Program, Faculty of Allied Health Sciences, Naresuan University, Phitsanulok, Thaila nd \\ 3 Department of Medical Technology, Faculty of Allied Health Sciences, Naresuan University, Phitsanulok, Thailand and Integrative Biomedical Research \\ Unit (IBRU) \\ ${ }^{4}$ Microbiology Laboratory, Department of Pathology, Faculty of Medicine Ramathibodi Hospital, Mahidol University, Ba ngkok, Thailand
}

\begin{abstract}
There is an increasing worldwide prevalence of carbapenems resistance in Enterobacteriaceae (CRE). The production of carbapenemase is the most important drug resistance mechanism. Several phenotypic-based detecting carbapenemase enzyme methods have been developed, including the modified Hodge test (MHT), the Carba NP test, the modified carbapenem inactivation method (mCIM), and other combined disk tests. Unfortunately, these methods are unable to differentiate between types of carbapenemase. The purpose of this study was to develop and verify the modified Carba NP test for carbapenemase enzymes differentiation by supplementing the carbapenemase inhibitors (clavulanic acid and dipicolinic acid). The clinical isolates of carbapenemase-producing Enterobacteriaceae were collected from Wichianburi and Phetchabun hospitals in Phetchabun province, Thailand. These clinical isolates were then determined using phenotypic and genotypic methods. The results show that the novel modified Carba NP test showed $100 \%$ specificity. Non-susceptible carbapenem was detected in 28/173 isolates (16.2) of Enterobacteriaceae, and only 5 isolates (2.9\%) of carbapenemase-producing Enterobacteriaceae were found. Genotypic analysis shows that these isolates habour the bla $a_{\mathrm{NDM}}$ of carbapenemase genes. Furthermore, the modified Carba NP test is considered to be an accessible method for identifying types of carbapenemase enzymes by using a microtiter plate, and the results can be interpreted within 15 and 90 minutes.
\end{abstract}

\section{Keywords:}

Carbapenem-resistant Enterobacteriaceae (CRE), Carbapenemase, Enterobacteriaceae, Carba NP test, Modified Carba NP test

\section{INTRODUCTION}

Multidrug resistance caused by various bacterial species is increasing rapidly throughout the world and is now a major concern for community-acquired and nosocomial infections ${ }^{1}$. One of the most multidrug resistant bacteria is Enterobacteriaceae, which is considered to be the most common pathogens in community and hospital-acquired infections, including urinary and gastrointestinal tract infections and increases disease severity and mortality ${ }^{2}$. The use of antibiotics is the only curative intervention, while carbapenem is considered to be the last option and highly effective drug to treat multidrug resistant bacterial infections, especially Enterobacteriaceae $^{3}$.

Among multidrug resistant bacterial infections, the prevalence of carbapenem-resistant Enterobactericeae (CRE) is reportedly increasing. The resistance mechanism to carbapenem has been mostly attributed to an ability to produce carbapenemase enzymes, rather than other mechanisms such as efflux pump and outer membrane alterations ${ }^{4}$. Carbapenemases are classified as $\beta$ lactamase enzymes, which are produced by gram-negative bacilli, including Enterobacteriaceae, Pseudomonas

*Corresponding author:

*Noppadon Jumroon noppadonj@nu.ac.th 
spp., and Acinetobacter spp $\mathrm{s}^{4}$.

The emergence of $\beta$-lactamases with direct carbapenem-hydrolyzing activity has contributed to the increasing prevalence of CRE. Carbapenemase, which is known as carbapenem-hydrolyzing enzyme, consist of three molecular classes, including classes A, B, and D. This enzyme has a hydrolysis ability to $\beta$-lactam antibiotics, including penicillin, cephalosporins, monobactams, carbapenems, and $\beta$-lactamase inhibitors ${ }^{5}$. The most common class A carbapenemases are Klebsiella pneumoniae carbapenemase (KPC), which has its gene encoded on plasmid and are commonly found in Enterobacteriaceae. KPC is inhibited by phenlylboronic acid (PBA) or clavulanic acid (CVA) ${ }^{6}$. Class B carbapenemases are metallo- $\beta$-lactamase enzymes (MBLs) which require zinc ions at their active site. Several MBLs have been reported, including New Delhi MBL (NDM), imipenem-resistant phenotype (IMP), and Verona integrin-encoded MBLs (VIM). These enzymes have been found in Enterobacteriaceae and non-fermentative gram-negative bacilli (Pseudomonas aeruginosa and Acinetobacter baumannii). Additionally, all the MBLs mentioned above can be inhibited by dipicolinic acid and chelating agents (EDTA) ${ }^{7}$. Class D carbapenemases include OXA-23-like, OXA-48-like, OXA-58-like. In particular, OXA-48-like is a common producing in Enterobacteriaceae, while OXA-23-like and OXA-58like are frequently detected in $A$. baumannii ${ }^{8}$.

Several phenotypic-based detection techniques of carbapenemase enzymes have been used, such as the Carba NP test, the modified Hodge test (MHT), the modified carbapenem inactivation method (mCIM) and other combined disk tests ${ }^{2}$. These methods have both advantages and disadvantages. For instance, the Carba NP test has several benefits such as low cost, speedy, reproducible, and it is highly sensitive and specific ${ }^{2}$. However, the Carba NP test is also known for its inability to differentiate between classes of carbapenemase enzymes. The modified Hodge test is an inexpensive, easy, and simple test with highly sensitive results for class A and D carbapenemase enzymes ${ }^{9}$, but this test was removed from the CLSI M100-S28 in 2018 due to its limitations in detecting class B carbapenemase, which is known to have a high production of carbapenemresistant Enterobactericeae ${ }^{10}$. It is therefore necessary to develop a new method which is easier, simpler, and sufficiently reliable for detection and classification of carbapenemase enzymes.

In this study, a novel phenotypic method called "Modified Carba NP test" was developed to detect carbapenemase enzymes in both standard and clinical isolated Enterobacteriaceae. The newly developed method was compare with the existing methods. Furthermore, the test's ability to classify carbapenemase production in Enterobacteriaceae was also evaluated.

\section{MATERIALS AND METHODS}

\subsection{Population and Sample}

For control bacterial isolates, three positive control bacterial strains harboring carbapenemase gene including $K$. pneumoniae ATCC BAA 1705 (bla $a_{\mathrm{KPC}}$ ), $E$. coli ATCC BAA $2452\left(b l a_{\mathrm{NDM}-1}\right)$ and $E$. coli $\mathrm{ATCC}$ BAA

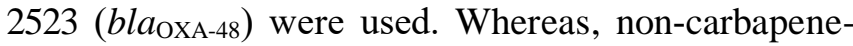
mase-producing Enterobacteriaceae isolates including E. cloacae ATCC BAA 1143 carrying AmpC gene $\left(\right.$ bla $\left.a_{\mathrm{AmpC}}\right)$, K. pneumoniae ATCC 700603 carrying ESBL gene $\left(\right.$ bla $\left._{\mathrm{SHV}-18}\right)$, E. coli ATCC 25922 (negative control) and K. pneumoniae ATCCBAA 1706 (no carbapenemaseencoding gene) were used as negative control bacterial strains.

Total of 173 bacterial clinical isolates of Enterobacteriaceae were collected between October 2016 and September 2017. There were 123 clinical isolated of Enterobacteriaceae from the Phetchabun hospital and 50 isolates from the Wichianburi hospital, Phetchabun province. All clinical isolates were collected from various clinical samples, such as urine, hemoculture, pus, sputum and ascetic fluid. They had been confirmed again by culturing on MacConkey agar and incubated at $35 \pm 2^{\circ} \mathrm{C}$ for $18-24$ hours. After that, the colonies were identified by the conventional biochemical tests, such as triple sugar iron (TSI), motility-indole-lysine medium (MIL), citrate, malonate and urease test.

\subsection{Antimicrobial susceptibility test}

Antimicrobial susceptibility test was performed by disk diffusion. A $0.5 \mathrm{McF}$ arland standard of bacterial suspension was applied on Mueller-Hinton agar and place imipenem, meropenem, ertapenem and doripenem disks (10 $\mathrm{mg}$ each) on medium, then incubated at $35 \pm$ $2^{\circ} \mathrm{C}$ for $16-18$ hours. Interpretation was a reading zone diameter according to CLSI guideline M100-S27 ${ }^{11}$.

\subsection{Phenotypic methods for detection of carbapene- mase enzymes}

\subsubsection{Modified Hodge test}

E. coli ATCC 25922 was an indicator and the suspension was adjusted to $0.5 \mathrm{McF}$ arland standard in $0.85 \%$ normal saline solution (NSS) and then dilute to 1:10 in NSS for swabbing on MHA according to CLSI M100-S27 guideline ${ }^{11}$. After 3-10 minutes, $10 \mathrm{mg}$ meropenem disk was placed on central of plate. Then, tested isolates, positive control, and negative control isolates were streaked in a straight line from disk to peripheral plate. The plate was incubated at $35 \pm 2^{\circ} \mathrm{C}$ for $16-20$ hours. Interpretation was performed by reading the enhancing growth of indicator organism into inhibition 
zone (cloverleaf). If there were an enhancing effect, the results were interpreted as a positive. If there were no enhancing growth of indicator organism into inhibition zone, the results were interpreted as a negative.

\subsubsection{Carba NP test}

According to CLSI M100-S2711, two solutions (solution A and B) were prepared by adding $2 \mathrm{ml}$ of $0.5 \%(\mathrm{w} / \mathrm{v})$ phenol red in $16.6 \mathrm{ml}$ distilled water, $180 \mu \mathrm{l}$ of $10 \mathrm{mM}$ zinc sulfate and adjust $\mathrm{pH}$ to $7.8 \pm 0.1$. The solution B was a solution A supplemented with $6 \mathrm{mg} / \mathrm{mL}$ of imipenem powder. One loopful of bacterial colonies was added in $100 \mu 1$ micro-tube of lysis buffer. Then, solution A and solution $\mathrm{B}$ were mixed into two different micro-tubes and incubate at $35 \pm 2^{\circ} \mathrm{C}$ for 2 hours. The positive was readout when the red color of phenol red in solution B changed to yellow.

\subsubsection{Modified Carbapenem Inactivation Method (mCIM)}

The modified carbapenem inactivation method (mCIM), developed by CLSI M100-S27 guideline ${ }^{11}$, is a phenotypic method for detecting the carbapenemase enzymes, with the sensitivity and specificity greater than $99 \%$.

Firstly, emulsified one loopful of bacteria in 2 $\mathrm{ml}$ of tryptic soy broth (TSB) and vortex for 10-15 seconds. Then, immersed the $10 \mathrm{mg}$-meropenem disk in suspension of TSB broth and incubated at $35 \pm 2^{\circ} \mathrm{C}$ for 4 hours \pm 15 minutes. Secondly, an indicator organism, E. coli ATCC 25922 was adjusted to $0.5 \mathrm{McFarland}$ standard in NSS and then swabbed on MHA. After 4 hours \pm 15 minutes, meropenem disk would be dragged from TSB broth by using loop and placed on MHA with indicator. Incubation was at $35 \pm 2^{\circ} \mathrm{C}$ for $16-18$ hours. The result would be read according to CLSI M100S27 guideline $^{11}$.

\subsubsection{Modified Carba NP test}

The principle of modified Carba NP test is the addition of inhibitors, such as dipicolinic acid (DPA) or/and clavulanic acid (CVA), in Carba NP solutions to block the activity of carbapenemase enzymes, which hydrolyze carbapenem drug (imipenem).

All isolates, which were positive either in MHT or Carba NP test, were examined by the modified Carba NP test. In sample preparation, $100 \mu 1$ lysis buffer was added to the $10 \mu \mathrm{l}$ of loop-full bacterial suspension, originally from colonies growth on MHA, and then centrifuged at $15,500 \mathrm{rpm}$ for 10 minutes at room temperature. The amount of bacteria inoculation was adjusted to $3 \mathrm{McFarland}$ standard (equal to $9 \times 10^{8} \mathrm{CFU} / \mathrm{ml}$ ) or over 3 McFarland standards.
Five wells per sample on 96-well plate were supplied with different reagents. The first well (labeled as $\mathrm{P}$ well) was positive control that contains $10 \mu \mathrm{l}$ of tested sample and solution $\mathrm{P}$ (imipenem and no inhibitor). The second well (A well) contained $10 \mu \mathrm{l}$ of tested sample and $70 \mu 1$ of solution A (imipenem plus dipicolinic acid), for class A carbapenemase identification. The third well (B well) contained $10 \mu 1$ of tested sample and $70 \mu 1$ of solution B (imipenem plus clavulanic acid) for class B carbapenemase identification. The fourth well (D well) was contained $10 \mu \mathrm{l}$ of tested sample and $70 \mu \mathrm{l}$ of solution D (imipenem plus both of dipicolinic acid and clavulanic acid) for class D carbapenemase identification. The fifth well ( $\mathrm{N}$ well) was negative control and solution $\mathrm{N}$ (no imipenem and no inhibitor). (Figure 1). After that these well were incubated at $35 \pm 2^{\circ} \mathrm{C}$ for 90 mins. The type of inhibitors and volume of reagents were demonstrated in Table 1.

\subsection{Genotypic Method}

Genotypic identification of carbapenemase gene of clinical isolates was performed by the fully-integrated, automated platform of BD MAX ${ }^{\mathrm{TM}} \mathrm{CRE}$ assay (Becton, Dickinson and Company, US) at microbiology laboratory, Department of Pathology, Faculty of Medicine Ramathibodi hospital, Mahidol University in Bangkok, Thailand. The primers used were those as previously described by Poirel et al. $(2011)^{12}$.

\section{RESULTS}

\subsection{Identification and antimicrobial susceptibility test of bacterial clinical isolate}

A total of non-duplicated 173 obtained clinical Enterobacteriaceae isolates, from Wichianburi hospital and Phetchabun hospital, were cultured and identified by conventional methods. The results showed that there were 50 Enterobacteriaceae isolates from Wichianburi hospital including, E. coli 27 isolates (54\%), K. Pneumoniae 15 isolates (30\%), Enterobacter spp. 4 isolates (8\%), P. mirabilis 2 isolates (4\%), C. diversus 1 isolate $(2 \%)$ and $S$. marcescens 1 isolate (2\%).

There were 123 isolates of Enterobacteriaceae from Phetchabun hospital, including $E$. coli 71 isolates $(57.72 \%), K$. pneumoniae 32 isolates $(26.02 \%), E$. cloaceae 12 isolates $(9.76 \%)$, P. mirabilis 3 isolates (2.44\%), C. freundii 2 isolates $(1.63 \%), S$. marcescens 2 isolates $(1.63 \%)$ and Salmonella spp. 1 isolate $(0.78 \%)$ as shown in Table 2 .

The antimicrobial susceptibility test was examined by disk diffusion to all identified Enterobacteriaceae, 50 isolates from Wichianburi hospital and 123 isolates from Phetchabun hospital. Only 11 isolates and 17 isolates, respectively, were non-susceptible to 
A.

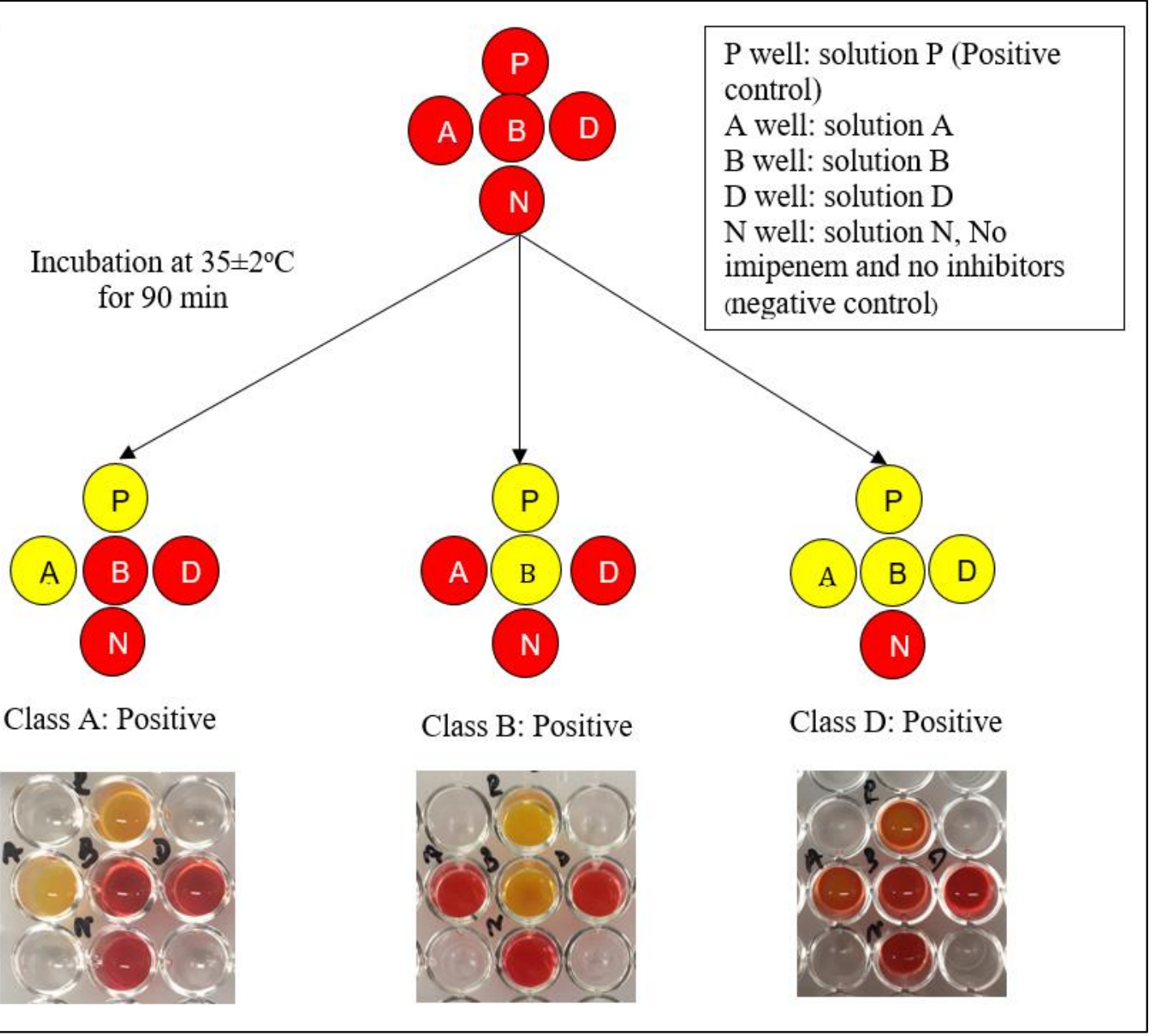

Figure 1. Modified Carba NP test. (A. Schematic of Modified Carba NP test, B. Color changing pattern of Modified Carba NP test)

Table 1. Inhibitors and volume of reagents for Modified Carba NP test.

\begin{tabular}{|c|c|c|c|c|c|c|}
\hline Solution & $\mathbf{N}$ & $\mathbf{P}$ & A & B & D & Per well $(70 \mu \mathrm{l})$ \\
\hline CLRW & $16.6 \mathrm{ml}$ & $16.6 \mathrm{ml}$ & $16.6 \mathrm{ml}$ & $16.6 \mathrm{ml}$ & $16.6 \mathrm{ml}$ & $58.1 \mu \mathrm{l}$ \\
\hline $0.5 \%$ Phenol red & $2 \mathrm{ml}$ & $2 \mathrm{ml}$ & $2 \mathrm{ml}$ & $2 \mathrm{ml}$ & $2 \mathrm{ml}$ & $7 \mu 1$ \\
\hline $10 \mathrm{mM}$ Zinc sulfate & $180 \mu 1$ & $180 \mu 1$ & $180 \mu \mathrm{l}$ & $180 \mu 1$ & $180 \mu 1$ & $0.0063 \mu 1$ \\
\hline $0.1 \mathrm{~N} \mathrm{NaOH}$ or $10 \% \mathrm{HCl}$ & \multicolumn{6}{|c|}{ As needed } \\
\hline Dipicolinic acid & No & No & $8.356 \mathrm{~g} / \mathrm{L}$ & No & $8.356 \mathrm{~g} / \mathrm{L}$ & $0.584 \mathrm{mg}$ \\
\hline Clavulanic acid & No & No & No & $1.187 \mathrm{~g} / \mathrm{L}$ & $1.187 \mathrm{~g} / \mathrm{L}$ & $0.83 \mathrm{mg}$ \\
\hline Imipenem & No & $6 \mathrm{mg} / \mathrm{ml}$ & $6 \mathrm{mg} / \mathrm{ml}$ & $6 \mathrm{mg} / \mathrm{ml}$ & $6 \mathrm{mg} / \mathrm{ml}$ & $0.42 \mathrm{mg}$ \\
\hline
\end{tabular}

CLRW: Clinical Laboratory Reagent Water

Table 2. A total of bacterial clinical isolates from Wichianburi and Phetchabun hospitals, Phetchabun province located in The Lower North region of Thailand.

\begin{tabular}{lccc}
\hline Organisms & \multicolumn{3}{c}{ Hospitals } \\
\cline { 2 - 4 } & Wichianburi (\%) & Phetchabun (\%) & Total (\%) \\
\hline E. coli & $27(54)$ & $71(57.72)$ & $98(79.67)$ \\
\hline K. pneumoniae & $15(30)$ & $32(26.02)$ & $47(38.21)$ \\
\hline E. cloacae & - & $12(9.76)$ & $12(9.76)$ \\
\hline Enterobacter spp. & $4(8)$ & - & $4(3.25)$ \\
\hline P. mirabilis & $2(4)$ & $3(2.44)$ & $5(4.07)$ \\
\hline S. marcescens & $1(2)$ & $2(1.63)$ & $3(2.44)$ \\
\hline C. freundii & - & $2(1.63)$ & $2(1.63)$ \\
\hline C. coseri & $1(2)$ & - & $1(0.81)$ \\
\hline Salmonella spp. & - & $1(0.81)$ & $1(0.81)$ \\
\hline Total & $\mathbf{5 0}(\mathbf{1 0 0})$ & $\mathbf{1 2 3 ( 1 0 0 )}$ & $\mathbf{1 7 3 ( 1 0 0 )}$ \\
\hline
\end{tabular}


carbapenem disk drugs. Therefore, the 28 isolates would be continually detected for carbapenemase enzymes.

\subsection{Detection of carbapenemase-producing bacterial clinical isolate by phenotypic and genotypic methods}

\subsubsection{Bacterial control strains}

Table 3 showed the verification of the modified Carba NP test by using the bacterial control strains compared with the existing phenotypic methods; MHT, Carba NP test, and mCIM.

The MHT test showed that $K$. pneumoniae ATCC BAA $1705\left(b^{\prime} a_{\mathrm{KPC}}\right)$, E. coli ATCC BAA $2452\left(\right.$ bla $\left._{\mathrm{NDM}-1}\right)$ and $E$. coli ATCC BAA 2523 (bla $a_{\mathrm{OXA}-48}$ ) were positive. For negative control strains of carbapenemase gene, including K. pneumoniae ATCC BAA 1706, K. pneumoniae ATCC BAA 700603 (bla SHV-18) and E. cloacae ATCC BAA $1143\left(b l a_{\mathrm{AmpC}}\right)$ were negative by MHT.

The Carba NP test demonstrated a slightly different results from MHT in the positive control strains. Only K. pneumoniae ATCC BAA 1705 (bla $\left.a_{\mathrm{KPC}}\right)$ and $E$. coli $\mathrm{ATCC}$ BAA 2452 (bla NDM-1 ) showed positive results whereas $E$. coli ATCC BAA 2523 (bla $a_{\text {OXA-48) }}$ became negative. However, all negative control strains, including K. pneumoniae ATCC BAA 1706, K. pneumoniae ATCC BAA 700603 (bla $\left.a_{\mathrm{SHV}-18}\right)$ and E. cloacae ATCC BAA 1143 (bla $\left.a_{\mathrm{AmpC}}\right)$ were negative by Carba NP test.

The results from modified Carbapenem Inactivation Method (mCIM), the positive and negative results were similar to the findings from MHT test, in which $K$. pneumoniae ATCC BAA 1705 (bla $\left.a_{\mathrm{KPC}}\right)$, E. coli $\mathrm{ATCC}$ BAA $2452\left(\right.$ bla $\left._{\mathrm{NDM}-1}\right)$ and $E$. coli ATCC BAA 2523 (bla $a_{\text {OXA-48) }}$ were positive with inhibition zone $6 \mathrm{~mm}, 6$ $\mathrm{mm}$ and $13 \mathrm{~mm}$, respectively.

The modified Carba NP test showed positive results for only two positive control strains, $K$. pneunomiae ATCC BAA 1705 (bla $\left.a_{\mathrm{KPC}}\right)$ and E. coli $\mathrm{ATCC} \mathrm{BAA}$ $2452\left(\right.$ bla $\left._{\mathrm{NDM}-1}\right)$. Whereas, E. coli ATCC BAA 2523 (bla $\left.a_{\text {OXA-48 }}\right)$ showed no change of color in Carba NP test and also in the modified Carba NP test, which could possibly be a false-negative result in both Carba NP test and the modified Carba NP test. Beside carbapenemaseproducing isolates, all non-carbapenemase-producing isolates including E. cloacae ATCC BAA 1143 (bla $\left.a_{\mathrm{AmpC}}\right)$, K. pneumoniae ATCC BAA 700603 (bla $a_{\mathrm{SHV}-18)}$ and $K$. pneumoniae ATCC BAA 1706 gave a negative readout by the modified Carba NP test. Therefore, the modified Carba NP test showed $66.66 \%$ sensitivity and 100\% specificity as shown in Table 3.

\subsubsection{Bacterial clinical isolates}

From 28 bacterial clinical isolates of carbapenemresistant Enterobacteriaceae, only one isolate of 11 carbapenem-resistant isolates from Wichianburi hospital gave a positive result by MHT test, which was identified as E. cloacae. However, it was negative by Carba NP test. So, this isolate was not included for the modified Carba NP test. In Phetchabun hospital, 5 isolates among 17 carbapenem-resistant isolates gave a positive result by MHT test, Carba NP test and mCIM test including P032 (C. freundii), P-095 (E. cloacae), P-102 (E. cloacae), $\mathrm{P}-104$ (E. cloacae), P-106 (K. pneumoniae) and P-115 (E. coli). Therefore, these 5 isolates were selected for classification of carbapenemase enzymes by the modified Carba NP test

The results showed that 5 isolates (from original 173 isolated in this study) (2.9\%) were positive for class B of carbapenemase enzyme, (Figure 2). Genotypic method demonstrated that all of them were found to carry $b l a_{\mathrm{NDM}}$ carbapenemase gene (Table 4 ).

\section{DISCUSSION}

A total of 173 Enterobacteriaceae clinical isolates from Phetchabun province in Thailand's lower northern region were studied. Of these were 123 clinical isolates from Phetchabun hospital and 50 clinical isolates from Wichianburi hospital. There were 28 of $173(16.2 \%)$ Enterobacteriaceae isolates found to be non-susceptible to carbapenem in both of the hospitals. These results show that the prevalence of carbapenem-resistant Enterobacteriaceae was higher than that found in other studies, such as Khon Kaen University's 2012 study which was only $2.2 \%$ among 4818 isolates ${ }^{13}$. Meanwhile, Yanglin $\mathrm{Xu}$ et al. reported less than $1 \%$ carbapenem-resistant Enterobacteriaceae in Thailand ${ }^{14}$. Recently, a study on the prevalence of carbapenemaseproducing carbapenem-resistant Enterobacteriaceae in Bangkok, Thailand used the Carba NP and mCIM tests to reveal that 223 of 287 isolates $(77.70 \%)$ carried at least one carbapenemase gene. In addition, 160 isolates $(71.75 \%)$ had an NDM gene, of which approximately $95.63 \%$ were NDM- $1{ }^{15}$. Nonetheless, these previous studies did not represent the prevalence of carbapenemase producing Enterobacteriaceae in Thailand overall, but rather showed the particular prevalence in local regions of Thailand.

As mentioned in the results section, one clinical isolate bacteria (E. cloacae) from Wichianburi hospital could provide a false positive for MHT. This could potentially be due to expectedly AmpC production, which is more likely to have resistance to imipenem than other carbapenems ${ }^{16}$. Moreover, class D carbapenemase may result in a positive readout for MHT. Tijet Nathalie et al. (2013) reported a false negative for the Carba NP test which was found to have a specificity of only $80 \%$, potentially due to the production of OXA48-like enzymes in the organisms ${ }^{17}$. Both Nordmann Patrice et al. (2012) and Laolerd Warawut et al. (2018) 


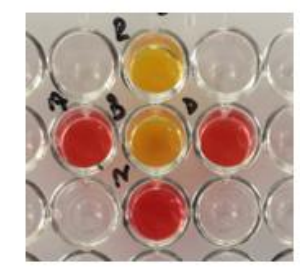

P-032 (C.freundii)

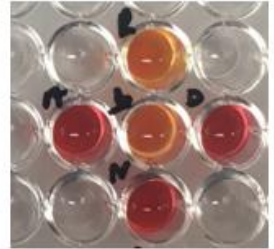

P-095 (E.cloacae)

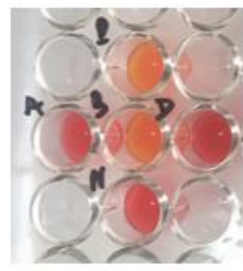

P-102 (E.cloacae)

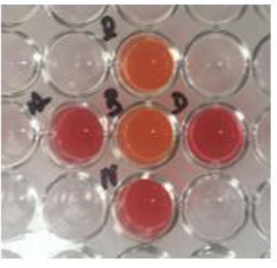

P-104 (E.cloacae)

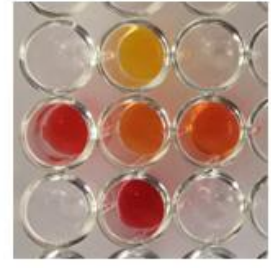

P-115 (E.cloacae)

Figure 2. Patterns of Modified Carba NP test in bacterial clinical isolates.

Table 3. Verification of the Modified Carba NP test with the bacterial control strains.

\begin{tabular}{|c|c|c|c|c|c|c|c|c|c|}
\hline \multirow[t]{3}{*}{ Bacterial strains } & \multirow[t]{3}{*}{ Gene } & \multicolumn{8}{|c|}{ Methods of carbapenemase detection } \\
\hline & & \multirow[t]{2}{*}{ MHT } & \multirow[t]{2}{*}{ Carba NP test } & \multirow{2}{*}{ mCIM (mm) } & \multicolumn{5}{|c|}{ Modified Carba NP test } \\
\hline & & & & & $\mathbf{P}$ & $\mathbf{A}$ & B & D & $\mathbf{N}$ \\
\hline \multicolumn{10}{|l|}{ Positive bacterial control strains } \\
\hline K. pneumoniae ATCC BAA 1705 & bla $\mathrm{KPC}$ & + & + & + & + & + & - & - & - \\
\hline E. coli ATCC BAA 2452 & blanDM-1 & + & + & + & + & - & + & - & - \\
\hline E. coli ATCC BAA 2523 & bla OXA-48 & + & - & + & + & - & - & - & - \\
\hline \multicolumn{10}{|c|}{ Negative bacterial control strains } \\
\hline $\begin{array}{l}\text { K. pneumoniae } \\
\text { ATCC BAA } 1706\end{array}$ & $\begin{array}{l}\text { No carbapene- } \\
\text { mase gene }\end{array}$ & - & - & - & - & - & - & - & - \\
\hline $\begin{array}{l}\text { K.pneumoniae } \\
\text { ATCC BAA } 700603\end{array}$ & blasHV-18 & - & - & - & - & - & - & - & - \\
\hline E. cloacae ATCC BAA 1143 & bla $a_{\mathrm{AmpC}}$ & - & - & - & - & - & - & - & - \\
\hline
\end{tabular}

Table 4. Results of bacterial clinical isolates by Modified Carba NP test.

\begin{tabular}{|c|c|c|c|c|c|c|c|c|c|c|c|c|c|c|}
\hline \multirow[t]{2}{*}{ Code } & \multirow{2}{*}{$\begin{array}{l}\text { Clinical } \\
\text { isolate }\end{array}$} & \multicolumn{4}{|c|}{$\begin{array}{c}\text { Disk diffusion } \\
\text { Zone of inhibition }(\mathrm{mm})\end{array}$} & \multirow[t]{2}{*}{ MHT } & \multirow{2}{*}{$\begin{array}{c}\text { Carba NP } \\
\text { test }\end{array}$} & \multirow{2}{*}{$\begin{array}{c}\text { mCIM } \\
(\mathbf{m m})\end{array}$} & \multicolumn{5}{|c|}{ Modified Carba NP test } & \multirow[t]{2}{*}{ Gene } \\
\hline & & MEM & ETP & DOR & IPM & & & & $\mathbf{P}$ & $\mathbf{A}$ & B & D & $\mathbf{N}$ & \\
\hline $\mathrm{P}-032$ & $\begin{array}{l}\text { C. freundii } \\
\text { (Urine) }\end{array}$ & 14 & 12 & 13 & 13 & + & + & $+(6)$ & + & - & + & - & - & $b l a_{\mathrm{NDM}}$ \\
\hline P-095 & $\begin{array}{l}\text { E. cloacae } \\
\text { (Urine) }\end{array}$ & 6 & 6 & 6 & 6 & + & + & $+(6)$ & + & - & + & - & - & bla $\mathrm{NDM}$ \\
\hline P-102 & $\begin{array}{l}\text { E. cloacae } \\
\text { (Pus) }\end{array}$ & 6 & 6 & 6 & 6 & + & + & $+(6)$ & + & - & + & - & - & $b^{\prime} l a_{\mathrm{NDM}}$ \\
\hline P-105 & $\begin{array}{l}\text { E. cloacae } \\
\text { (Urine) }\end{array}$ & 6 & 6 & 6 & 6 & + & + & $+(6)$ & + & - & + & - & - & $b l a_{\mathrm{NDM}}$ \\
\hline P-115 & $\begin{array}{l}\text { E. coli } \\
\text { (Urine) }\end{array}$ & 10 & 6 & 14 & 13 & + & + & $+(6)$ & + & - & + & - & - & $b l a_{\mathrm{NDM}}$ \\
\hline
\end{tabular}

MEM: Meropenem, ETP: Ertapenem, DOR: Doripenem, IPM: Imipenem, MHT: modified Hodge test, mCIM: modified Carbapenem Inactivation Method. 
reported that the Carba NP test had a sensitivity of $100 \%$ for Enterobacteriaceae ${ }^{2,15}$.

According to CLSI guidelines, the incubation duration of the Carba NP test is 2 hours. Srisrattakarn Arpasiri et al. explained that the paper strip test could be performed within 1 to 5 minutes ${ }^{18}$, but in present study demonstrated that the good incubation period is between 15 and 90 minutes. The paper strip test may reduce the incubation time, unfortunately, it is unable to differentiate the class of carbapenemase enzymes. For inoculation, the amount of the cell compared with the McFarland standard would equal or be over 3 McFarland standard. Meanwhile, CLSI guideline and Pasteran Fernando et al. recommends $10 \mu$ loop-full ${ }^{19}$.

In this study, class A carbapenemase enzyme was not inhibited by 3-aminophenylboronic acid, a finding which differs from Girgis CG et al. (2015) which showed the application of boronic acid disk to detect class A carbapenemase production in K. pneumoniae. However, several reports reviewed that the activity of 3 -aminophenylboronic acid was inhibited by class A carbapenemase production in $K$. pneumoniae $e^{6,20-21}$ and could result in KPC-producing $K$. pneumoniae detection to have $100 \%$ sensitivity and $98 \%$ specificity ${ }^{22}$.

Although the classification of carbapenemase enzymes by the modified Carba NP test demonstrates high specificity (100\%), particularly for classes A and $\mathrm{B}$, it may be the least sensitive method (sensitivity of $66.66 \%)^{20,22}$. For the activity of OXA-48 enzyme, the modified Carba NP test was not different from the Carba NP test ${ }^{2}$. Both of these tests demonstrated a false negative to OXA-48 producing isolates, resulted in the less sensitivity of the modified Carba NP test. There are several phenotypic methods for carbapenemase enzyme detection, but only a few are able to differentiate the class of carbapenemase and they have limitations. Currently, there is no single phenotypic method that could be used to detect and differentiate carbapenemase enzymes $^{23}$. The limitations of the present study are that the clinical isolates used were only collected from Phetchabun province, Thailand and all 5 carbapenemaseproducing isolates produced NDM enzyme which is the most prevalent enzyme produced by Enterobacteriaceae in Thailand. It is necessary to evaluate and validate the various type of carbapenemase enzymes produced from bacterial control strains and clinical isolates, especially OXA-like in class D carbapenemase enzymes.

In the present study, the modified Carba NP test resulted in only 5 of the 173 isolates having a positive readout as class B carbapenemase, which were later confirmed to harbour bla $a_{\mathrm{NDM}}$. This finding is similar to Rimrang Benchamas et al. (2012) which demonstrated the emergence of $b l a_{\mathrm{NDM}-1}$ and $b l a_{\mathrm{IMP}-14 \mathrm{a}}$-carrying Enterobacteriaceae in Thailand ${ }^{13}$. Together with Srisrattakarn Arpasiri et al. (2016) showed that there were 125 of 137 carbapenemase-producing Enterobacteriaceae and Pseudomonas spp. in three different hospitals (Nan hospital, Srinagarind hospital and The Queen Sirikit National Institute of Child Health) which also carried $b l a_{\text {NDM }}$ and bla $_{\text {OXA-like }}{ }^{18}$. Nonetheless, carbapenemase detection requires a genotypic assay to precisely identify carbapenamase genes. Further study is required into molecular techniques, which remain the gold standard for epidemiological investigations.

\section{CONCLUSION}

In conclusion, the modified Carba NP test is a new method that can detect and differentiate the class of carbapenemase enzymes. Although this method was found to have a low sensitivity compared to the combined-disk test and double-disk synergy test, it is easy to perform by using 96-well plate and adding the inhibitors (clavulanic acid and/or dipicolinic acid). It is also simple to read and interpret the results within 15 to 90 minutes, whereas the combined-disk test or disk-synergy test require 16 to 18 hours. Therefore, the modified Carba NP test is a novel, easy, and fast method to differentiate the class of carbapenemase enzymes.

\section{ACKNOWLEDGMENT}

We are grateful to Sukanya Chokngam, Narumol Bunchaiyang, and Natthavut Tokokgoat from Wichian Buri and Phetchabun Hospital, Phetchabun for providing clinical isolates and we thank Assist. Prof. Dr. Sarawut Kumphune, Faculty of Allied Health Sciences, Naresuan University, for comments on manuscript.

\section{Author Contributions}

Bore Kong and Noppadon Jumroon conceived and designed the experiments; Bore Kong and Farida Noothong performed the experiments; Bore Kong and Noppadon Jumroon analyzed the data; Noppadon Jumroon contributed reagents/materials/analysis tools; Bore Kong and Noppadon Jumroon wrote and prepared the manuscript; Bore Kong, Farida Noothong, Noppadon Jumroon, Panyupa Pankhong, and Pitak Santanirand corrected, reviewed, and commented the manuscript.

\section{Conflicts of Interest}

The authors declare no conflicts of interest.

\section{Funding}

This study was financially supported by Naresuan University (Grant ID number R2558C168). We would like to thank the scholarship from Her Royal Highness Princess Maha Chakri Sirindhon providing for Bore Kong.

\section{Ethics approval}

Naresuan University Institutional Review Board COE No.102/2015 and IRB No.266/58. 


\section{Article info:}

Received December 5, 2020

Received in revised form March 22, 2021

Accepted May 23, 2021

\section{REFERENCES}

1. Tang HJ, Lai CC, Chen CC, Zhang CC, Weng TC, Chiu YH, et al. Colistin-sparing regimens against Klebsiella pneumoniae carbapenemase-producing K. pneumoniae isolates: Combination of tigecycline or doxycycline and gentamicin or amikacin. J Microbiol Immunol Infect. 2019;52:273-81.

2. Nordmann P, Poirel L, Dortet L. Rapid detection of carbapenemase-producing Enterobacteriaceae. Emerg Infect Dis. 2012; 18:1503-07.

3. Fursova NK, Astashkin EI, Knyazeva AI, Kartsev NN, Leonova

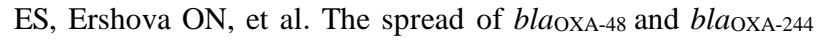
carbapenemase genes among Klebsiella pneumoniae, Proteus mirabilis and Enterobacter spp. isolated in Moscow, Russia. Ann Clin Microbiol Antimicrob. 2015;14:46.

4. Bakthavatchalam YD, Anandan S, Veeraraghavan B. Laboratory detection and clinical implication of oxacillinase-48 like carbapenemase: the hidden threat. J Glob Infect Dis. 2016;8:41-50.

5. Bush K, Jacoby GA. Updated functional classification of betalactamases. Antimicrob Agents Chemother. 2010;54:969-76.

6. Hammoudi D, Moubareck CA, Sarkis DK. How to detect carbapenemase producers? A literature review of phenotypic and molecular methods. J Microbiol Methods. 2014;107:106-18.

7. Miriagou V, Cornaglia G, Edelstein M, Galani I, Giske CG, Gniadkowski M, et al. Acquired carbapenemases in Gram-negative bacterial pathogens: detection and surveillance issues. Clin Microbiol Infect. 2010;16:112-22.

8. Poirel L, Naas T, Nordmann P. Diversity, epidemiology, and genetics of class D beta-lactamases. Antimicrob Agents Chemother. 2010;54:24-38

9. Birgy A, Bidet P, Genel N, Doit C, Decré D, Arlet G, et al. Phenotypic screening of carbapenemases and associated $\beta$-lactamases in carbapenem-resistant Enterobacteriaceae. J Clin Microbiol. 2012;50:1295-302.

10. Clinical and Laboratory Standards Institute (CLSI). Performance standards for antimicrobial susceptibility testing M100-S28, $28^{\text {th }}$ edn. Clinical and Laboratory Standards Institute (CLSI), Wayne, PA, USA; 2018.

11. Clinical and Laboratory Standards Institute (CLSI). Performance standards for antimicrobial susceptibility testing M100-S27, 27 $7^{\text {th }}$ edn. Clinical and Laboratory Standards Institute (CLSI), Wayne, PA, USA; 2017.

12. Poirel L, Walsh TR, Cuvillier V, Nordmann P. Multiplex PCR for detection of acquired carbapenemase genes. Diagn Microbiol Infect Dis. 2011;70(1):119-23.

13. Rimrang B, Chanawong A, Lulitanond A, Wilailuckana C, Charoensri N, Sribenjalux P, et al. Emergence of NDM-1- and IMP-14a-producing Enterobacteriaceae in Thailand. J Antimicrob Chemother. 2012;67:2626-30.

14. Xu Y, Gu B, Huang M, Liu H, Xu T, Xia W, et al. Epidemiology of carbapenem resistant Enterobacteriaceae (CRE) during 20002012 in Asia. J Thorac Dis. 2015;7:376-85.

15. Laolerd W, Akeda Y, Preeyanon L, Ratthawongjirakul P, Santanirand P. Carbapenemase-producing carbapenem-resistant Enterobacteriaceae from Bangkok, Thailand, and their detection by the Carba NP and modified carbapenem inactivation method tests. Microb Drug Resist. 2018;24:1006-11.

16. Thomson KS, Sanders CC. Detection of extended-spectrum beta-lactamases in members of the family Enterobacteriaceae: comparison of the double-disk and three-dimensional tests. Antimicrob Agents Chemother. 1992;36:1877-82.

17. Tijet N, Boyd D, Patel SN, Mulvey MR, Melano RG. Evaluation of the Carba NP test for rapid detection of carbapenemase- producing Enterobacteriaceae and Pseudomonas aeruginosa. Antimicrob Agents Chemother. 2013;57:4578-80.

18. Srisrattakarn A, Lulitanond A, Wilailuckana C, Charoensri N, Wonglakorn L, Piyapatthanakul S, et al. Modification and evaluation of the Carba NP test by use of paper strip for simple and rapid detection of carbapenemase-producing Enterobacteriaceae. World J Microbiol Biotechnol. 2016;32:117.

19. Pasteran F, Tijet N, Melano RG, Corso A. Simplified protocol for Carba NP test for enhanced detection of carbapenemase producers directly from bacterial cultures. J Clin Microbiol. 2015;53:3908-11.

20. Thomson KS. Extended-spectrum-beta-lactamase, AmpC, and Carbapenemase issues. J Clin Microbiol. 2010;48:1019-25.

21. Tsakris A, Poulou A, Bogaerts P, Dimitroulia E, Pournaras S, Glupczynski Y. Evaluation of a new phenotypic OXA-48 disk test for differentiation of OXA-48 carbapenemase-producing Enterobacteriaceae clinical isolates. J Clin Microbiol. 2015;53: 1245-51.

22. Giske CG, Gezelius L, Samuelsen Ø, Warner M, Sundsfjord A, Woodford N. A sensitive and specific phenotypic assay for detection of metallo- $\beta$-lactamases and KPC in Klebsiella pneumoniae with the use of meropenem disks supplemented with aminophenylboronic acid, dipicolinic acid and cloxacillin. Clin Microbiol Infect. 2011;17:552-6.

23. Tamma PD, Simner PJ. Phenotypic detection of carbapenemaseproducing organisms from clinical isolates. J Clin Microbiol. 2018;56:e01140-18. 